\title{
Philosophical Affinity between Tagore and Sufi Poets of Iran
}

Niaz Ahmed Khan

\begin{abstract}
India and Iran have centuries' old bond of socio-cultural, philosophical and mystical pursuits firmly deep rooted in the socio-ethical lives of both the countries. They have ever been a potential breeding ground for spiritual endeavours and philosophical reflections. With the advent of Islam there upon the genesis and development of Sufi movement in Iran side by side the Bhakti movement here in India brought both the nations close to each other to interact and share their spiritual gains. These two countries produced many luminaries throughout the ages immemorial. Among them Hafiz, Rumi in Iran and Tagore in India outshined their predecessors in their philosophical outlook and humanistic approach. The present article is a humble attempt to trace, find out and correlate the thread of common elements much pertinent to their works.
\end{abstract}

Key Words: Mysticism, humanism and Philosophy

$$
\text { زين قند شيارسى شو شه به همه طوطا له ميان هند رود }
$$

All the parrots (poets) of India will be overwhelmed By the sweetness of this sugar candy of Persia that goes to Bengal

Some centuries ago a ruler of Bengal once invited Hafiz Shirazi the divine tongued Persian poet of Iran but owing to his advanced age thereupon strenuous journey involved in he could not venture out and just sent a ghazal in response to that containing this famous couplet. Down a trail of centuries later a sun rose from 
the eastern horizon of Bengal and gradually soaring high reached his zenith to spread luminosity throughout the world whose poetic attainment name and fame made every Asian country to be proud of and consider him to be their own. The zephyr bearing the fragrance of his poetic excellence reached and overwhelmed the Iranian people as well and subsequently prompted the king of Iran Reza Shah Pahlavi to extend an invitation not only to acknowledge and felicitate him for his literary achievements and humanistic reflections but also to see the legacy of their own poetic genius getting embodied in the form of an Indian poet known as Rabindranath Tagore. The emotional and intellectual affinity could be seen through these words of the poet expressed subsequent upon his journey to Persia in the year 1932, "Persians have a passion for poetry, a genuine affection for their poets and I have obtained a share of this affection without having to show any thing for it in return ${ }^{1}$... so they are looking on me as a blood relation, on top of that the rumor has gone forth that my poems have an affinity with those of their favorite mystic poets of old. ${ }^{2}$ Once I got acquainted with Iran from distance in my childhood days. The image of Iran was a land of poets, reflections, and of imaginations. Its language was Persian and the message was altogether for the whole of humanity. My father was a passionate fan of Hafiz. He used to recite the couplets of Hafiz and explain it to me. The image of Iran was drawn through these verses on the canvas of my mind. ${ }^{3}$ Sitting at the tomb of Hafiz suddenly I realized a flash of light releasing from the gleeful eyes of the poet of Shiraz and having travelled through many ages reflected upon my heart. It seems as if we both were co-drinkers in the same tavern savoring many cups of the wine of Gnosticism. ${ }^{4}$

This is a known fact that Maharishi Devendranath Tagore who was a staunch follower of the social reformist movement of Brahmo Samaj started by Raja Ram Mohan Roy had a great interest in the mystic poetry of Hafiz Shirazi. His liking for Hafiz was so deep that every day he used to recite some couplets of Hafiz's ghazal side by side the hymns of Upanishad in his morning prayer. It may also be noted that Raja Ram Mohan Roy was himself a great 
scholar of Arabic, Persian and an author of 'Tohfatul Movahedin' (The gift of monotheists). Thus there was a congenial atmosphere conducive to mystic pursuit both in and outside Tagore's family ambit. In such a favorable surrounding of mystic cherishment the young Rabindranath Tagore was nourished, educated and trained under the proficient patronage of his father who himself had a mystic bent of mind, "My father was a great scholar .He was intoxicated with Hafiz's verses. When I was a boy I often used to listen to his recitation of those poems and he translated them to me with a fervor of enjoyment that touched my heart... It brings to my mind once again how my father to the end of his days derived deep consolation from your poet's songs assimilating them in his devotional life." ${ }^{15}$ And thus he developed longing inclination towards Persian poetry especially those of Sufi poets of Iran like Hafiz and Rumi who were great exponents of the philosophy of unity of being and monotheism. Tagore in his offering songs has explicitly shown his monotheistic outlook and he believes that God is not separate from us. He is not confined to any particular place nor can His presence be evidently seen in places of worship rather he can be realized in the temple of man's own existence and everywhere on earth. So he says:

"O God you are crystallized in the fire and even dwell in water

You have encompassed everything and I before such a God bow my head and prostrate in submission"

And again he says:

Thou art the sky and thou art the nest as well

O thou beautiful, there in the nest it is thy love

That encloses the soul with color, sounds and odour. ${ }^{6}$

Such monotheistic ideas are found in some of the verses of Baba Tahir the Persian poet:

$$
\begin{aligned}
& \text { به دريا بنغرم دريا ته وينم } \\
& \text { به صحر ا بنكرم صحر ا تها وينم } \\
& \text { به هر جا بنكرم كوهو درودشت نشان از قامت زيبا تهه وينم7 }
\end{aligned}
$$


Philosophical Affinity between Tagore and Sufi Poets of Iran

I look at the desert I find the vastness of you

Where ever I look at mountain, plains or forest

I behold the manifestations of your beauty.

The human soul has ever been craving for union with the eternal soul ever since its separation at the time of creation. This pang of separation has ever been a moving spirit behind expression of every tender feeling:

"It is the pang of separation that spreads throughout the world and gives

birth to shapes innumerable in the infinite sky.

It is the sorrow of separation that gazes in silence all night from star to

star and becomes lyric among rustling leaves in rainy darkness of July.

It is this overspreading pain that deepens into loves and desires, into

sufferings and joys in human homes; and it is this that ever melts and

flows in songs through my poet's heart."

Jalaluddin Rumi expresses the same feelings in an allegorical way:

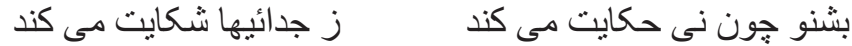

$$
\begin{aligned}
& \text { كز نيستان تا مر ا ببريده اند }
\end{aligned}
$$

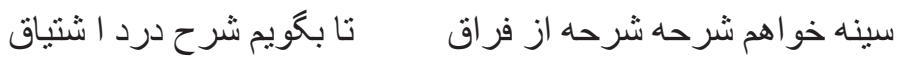

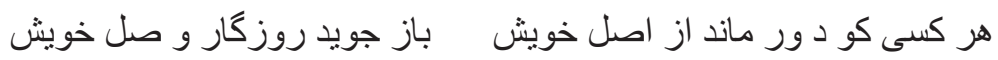

$$
\begin{aligned}
& \text { آتش ست اين بانع ناى و نيست باد هر كه اين آتش ندارد نيست باد } \\
& \text { آتش عشق است كاندر نى فتاد } \\
& \text { جو شُش عثق است كاندر مى فتاد9 }
\end{aligned}
$$


Listen to this flute that spreads melody when played

It is rather moaning on its separation from its bed

Ever since I am cut off from the reed bed

Men and women have come to tears on my bewailing

I want a chest torn off with pang

To listen to my woeful tale of longing and pain

Everyone who is separated from his source of origin

Ever looks for a chance to get united with the aimed

The melodious wind blown off the flute is not the wind but fire

Every breathing soul devoid of this fire is worth of no existence

It is the fire of love ignited in the flute

It is the surge of love blended with the bubbling wine.

The glowing shine of Rumi's thoughts not only illuminated his time and region but also surpassed the barrier of time and space to spread over throughout the world attracting the people of vision and pursuers of truth the omnipresent, omniscient ever swaying to and fro engulfing the whole of creation but still hard to perceive.

By going through the songs of Tagore it is evident that there is a strong bond of similarity between the two exponents of mystic pursuits based on their belief in the unity of being, love, music, exploring the infinite silence of inner self, the melody of flute and jiate mora (annihilation to the eternal truth)

One of the most striking similarities between Rumi and Tagore is their perception of love. Both of them consider the love as a seminal factor of creation, the basic element of existence and a moving spirit to keep the world in motion. Tagore says: "Yes, I know, this is nothing but thy love, O beloved of my heart- this golden light that dances upon the leaves, these idle clouds sailing across the sky, this passing breeze leaving its coolness upon my 
Philosophical Affinity between Tagore and Sufi Poets of Iran

forehead. The morning light has flooded my eyes- this is thy message to my heart. Thy face is bent from above, thy eyes look down on my eyes, and my heart has touched thy feet." ${ }^{\prime 10}$

Strikingly similar ideas are expressed by Rumi too in a different way:

$$
\begin{aligned}
& \text { عشق جوشد بحر را مانند د يع عثق سايد كوه را مانند ريع }
\end{aligned}
$$

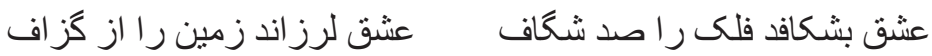

$$
\begin{aligned}
& \text { هر كرا جامه زعشق جاك شد او زحرص وجمله عيبى باك شد }
\end{aligned}
$$

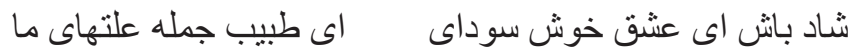

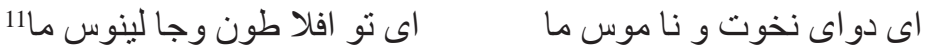

It is the love that simmers the sea like boiler

It is the love that grinds the mountain unto sand

It is the love that tears sky into hundred parts

It is the love that tremors the earth with its extravagance

Whose ever garment is torn in some one's love

He gets purified from greed lust and all ills

Be happy $O$ the jubilant love-mania

$O$ the physician of all ailments

$O$ the remedy of pride and prejudices

$O$ you the Plato and Galen of us

And Tagore said, "My life is derived from love. This world is mortal but the love is ever lasting. Everything will perish except love which will ever remain in its original shape to train human soul to reach his goal" and further he says, "The world of mine is sustained with the fire of love" 12

Silence is another way of expression. At many instances in Mathnavi of Jalaluddin Rumi we come across a juncture where the incredibility of speech and tongue in expressing concealed 
reflections of heart as well as poet's own unwillingness to bank upon word and articulate sounds are evidently seen. He believes that accomplishment of love lies in its inexpressive tongue. So he says:

$$
\begin{aligned}
& \text { كرجه تفسير زبان روشن كر است } \\
& \text { ليك عشق بـ زبان روشن نر است } \\
& \text { حرف و صوت و كفت را برهم زنم } \\
& \text { تا كه بى اين هر سه بانو دم زنم13 }
\end{aligned}
$$

Though the eloquence of language is expressive

But inarticulate love is more explicit

I put aside letter, sound and the word

So as to talk to you without all these aids.

Tagore too is in search of the language of heart and is willing to compose such a song that could be listened to by the ear of soul not by the ear of physical body; "My real tongue is engrossed in creating art somewhere in the depth of spell bound silence of soul and it lies in a realm where inarticulate imagination is wandering to find some expression." ${ }^{14}$

"It is the will of my Lord not to sing any ringing song.

So I henceforth got on to compose silent song"

Love for humanity is one of the basic traits of Sufism. Likewise the very teaching of Tagore is based on love for human beings.

Leave this chanting and singing and telling of beads!

Whom dost thou worship in this lonely dark corner of a temple?

With doors all shut

Open thine eyes and see thy God is not before thee.

$\mathrm{He}$ is there where the tiller is tilling the hard

Ground and where the path maker is breaking stone 
Philosophical Affinity between Tagore and Sufi Poets of Iran

$\mathrm{He}$ is with them in sun and in shower and

His garment is covered with dust

Put off thy holy mantle and even like him come down

On the dusty soil. ${ }^{15}$

In the same vein a great Sufi poet of Persia Sk. Sa'adi Shirazi says:-

$$
\begin{aligned}
& \text { بنى آدم اعضاى يكد يكر اند كه در آفرينش ز يك كوهر } \\
& \text { جو عضوى بدرد آورد روزكار ديكر عضوهار را نماند قرار } \\
& \text { تو كه از درد ديكر ان بى غمى شنايد كه نامت نهيد آدمى }
\end{aligned}
$$

Human beings are the limbs of each other

As they are created from a single essence

If unfavorable time inflicts harm on any part of body

The other parts do not remain at rest

If you are indifferent to the woes of others

You don't deserve to be called man.

Tagore not only explored and experienced the inner world but also paid attention to the materialistic world of deeds and reasons. Such vision of Tagore brought him close to Islamic وان يسن للا نس ء لا ما" "teachings that decreed in the Quranic verse, "And that man can have nothing but what he does (good or bad)"16 Tagore believes that the work gives man purity and piety and brings him close to his creator. This belief of him reminds the mystical spirit of Rumi who is immensely influenced by that Quranic verse. Tagore is endowed with a talent superfluous with art and aesthetic taste blended with ethical virtues that make the man come close to the world of humanity. He has mastery over music and art. Music to him is the language of soul and art is the mean to get close to the nature. Religion to him is based on ethics (doing good to humanity) the seminal philosophy of Sufism. 
The mysticism in Iran since the fourth century AH onward interacted with prevalent religious traits like the religion of Sun worship, dualism of Zoroastrianism the doctrine of Manichaeism especially in Khorasan by coming across with the world outlook of Taoism of China, Buddhist and Hindu mystical pursuits of India as well as the new platonic philosophy of Alexandria. Thus it becomes more florid more comprehensive. 'Love to eternal truth, the basic principle of Sufism, roots through love to human being' is believed to have been derived from the religion of Sun worship. Likewise the practice of yoga subscribing for the purification of self and to break the fetters of materialistic bondage so as to be able to discern the metaphysics through character, asceticism and spiritual pursuits. The Buddhist teachings not only influenced the Mani religion in Iran but also gave color to many Islamic beliefs and convictions. ${ }^{17}$ The concept of Jeyete mora (die before death) propounded by bouls of Bengal an outshoot of Sahajia movement of Buddhism is reflected in the verse of Sanai a great Sufi poet of Iran,

$$
\text { كمير اى دوست بِيش از مرگ ادر مى زندگى خو اهى إنى }
$$

O friend die before it the death comes if you want to live long

That Idris got salvation through such a death before us.

An thus Jalaluddin Rumi defines the Hadith, “مو تو قبل ان تمو تو"

In the following verses;

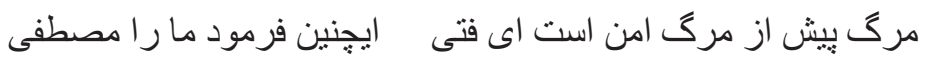

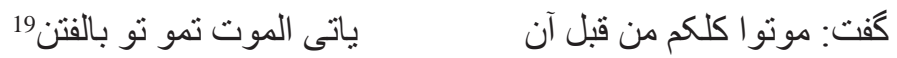

It is safe to die before death $O$ generous man

So told us the Prophet in these words

You die all before the death comes

And thus puts you on trial 
The voluntary death in Sufism is like the Nirvana of Buddhism. The Sufis have classified the death in two categories the voluntary and the compulsory and again the voluntary death is divided into four kinds as Haji Mulla Hadi Sabzwari said;

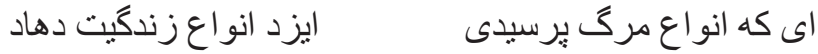

$$
\begin{aligned}
& \text { اضطر ارى موت معلوم است اختيار ى او جهار افتاد } \\
& \text { موت ابيض كه هست جوع و عطش در رياضيات باشروط رشاد } \\
& \text { موت اخضر موقع اندوزى در زنى جون درعه هاد } \\
& \text { موت اسود كه شد بلاى سياه احتمال ملامت است و عناد } \\
& \text { موت احمركه رنع خون آرد باشد اينجا خلاف نفس جهاد20 }
\end{aligned}
$$

O people that enquired the kinds of death

May God bless you with the variety of life

The Compulsory Death is known to all

The Voluntary Death comes of four kinds

The White Death is to sustain hunger and thirst

For self mortification with firmness indeed

The Green Death is to mend patches of rag

And to put on like a shield of ascetics

The Black Death is nothing but dark omen

That involves reproaching and perverseness

The Red Death bears red color

That is to go on crusade and fight against passion.

There is a common agreement between Indian philosophy and that of Islamic mysticism.

Tagore and Rumi believe that the eternal truth is not an external entity but an internal vitality. He is not to be sought for anywhere 
outside but within oneself. Rumi on the line of

Quranic verse نحن اقرب عليه من حبل الوريد"We are closer to him than (his) jugular vein", says:21

$$
\begin{aligned}
& \text { اى قوم به حج كجا ئيد كجا ئيد معشوق همين جاست بيا ئيد بيا ئيد } \\
& \text { آنانكه طلبكار خد ائيد خد ائيد حاجت به طلب نيست شمائيد شمائيد }
\end{aligned}
$$

O people where are you up to for pilgrimage

The beloved is here come on and come forth

Those of you who long for God

You need not to go wrong it's you it's you only.

The sect of Boul whose discernment had a great effect on the poetic vision of Tagore too believes in the conscientious existence of God in the form of 'Moner Manush', the Man of Heart.

With the realization of self

One can realize God

The formless God

In the shape of this form

Plays a continuous play

The God of gods is not separate from

The citadel that Master of sublime throne

Is this heart alone

One who realizes self so he realizes God

As it is known to all

In words of Nabi

Be attentive holding breath

With soul and heart together

In the presence of that formless form 
Philosophical Affinity between Tagore and Sufi Poets of Iran

Where the lovers having been annihilated

Ever move around

Fakir Lalan Shah says

This is the way to worship God.22

Tagore believes in the unity of being so he looks for the eternal beloved in paddy field in season's changes, in rain drops, in the sun light, in nature's manifestations and melody of flute that gives traces of dancing presence of Bideshani the unknown beloved ever shying away but intimately close to heart and soul. The omnipresent the omniscience being is not confined to any particular place of worship rather prevails upon everything and is very close to heart. So to find him one need not go and search outside but within him where he resides. The only need is to pull down the curtain of ego which hinders the glimpse of Him.

$$
\begin{aligned}
& \text { اندر دل من درون و بيرون همه اوست } \\
& \text { اندر تن من جان و رگ و خون همه اوست } \\
& \text { اينجا جُّونه كفر و ايمان كَنجد } \\
& \text { بيجّون باثند و جود من جون همه او }
\end{aligned}
$$

Within and outside my heart there is nothing but him

Within my body the soul the vein and blood He

How faith and infidelity find a place there

When the whole of my existence is nothing but him

Life is not a mere culmination of breathing in and out rather it is a continuous process of evolution of this earthly body to attain the state of divinity the cherished goal of every longing soul. Rumi says he passed through many stages of life to get on to the other one so as to reach the higher one until the blissful state of divinity. Thus death is not the end of life but a juncture is a continuous process of evolution towards getting accomplishment 
by being Fina-fillah, the total annihilation of self into the eternal truth called Nirvana, the salvation.

$$
\begin{aligned}
& \text { از جما دى مرد م و نامى شد م و ز نما مردم به حيوان سر دم }
\end{aligned}
$$

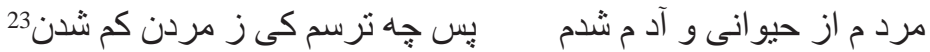

I died of inanimate to become enliven

I died of animate to get into animal sphere of life

I passed through animal life to become man

So why should I be afraid of death that makes me of no less

Tagore also expresses the same thought in a different way.

Thou hast made me endless, such is thy pleasure

This frail vessel thou emptiest and again

Fillest it ever with fresh life...ages pass and

Still thou pourest and still there is a room to it. ${ }^{24}$

The whole of universe is created and governed by love. Everything whether it is dust particles, light particles', dewdrops, the vast ocean on earth or the whole of celestial bodies and beyond everything is under the sway of love. So we the human being created out of these elements inherit the same characteristics.

$$
\text { جز عشق نبود هيج دمساز مرا }
$$

There was nothing but the love ever with me So I have no beginning or end as such (Rumi) Thou art the sky and thou art the nest as well $O$ thou beautiful there in the nest it is thy love That encloses the soul with colors and sounds and odours ${ }^{25}$

Tagore believes that the manifestation of God is everywhere in everything whether it is cultivation of field, the blossoming of spring time, the light spread over the whole of 
universe or tin the melody of flute whose thrilling song enchants not only the man and animals but inanimate plants too.

The same thought is expressed by Sk. Sa'di of Shiraz in the following couplet:

$$
\text { دفرگ هر كل در نظر هشيار }
$$

Every petal of rose in the eyes of a wise

Is a complete book of insight for about God

Thus both Tagore and Sufi poets of Iran though lived in different times in different geographical regions and in different socio religious ethos sang their love songs in different lingual expressions but however they spoke in the same language, the language of love and divinity rooted through eternity. Thus in the words of Tagore;

"The spring time is hospitable. Her birds in their music, her flowers in their fragrance speak a language which is universal needing no translation to explain them. They make no discrimination in favor of their own land of origin and their call of beauty which is God's own voice of love comes direct to my heart even though I am a traveler from far away shore.

The poet also represents the eternal springtime of hospitality. His message is in his music which invokes the harmony of perfection for all humanity; his invitation is to the comradeship in a festival of love's union."26

\section{NOTES}

1. Journey to Persia, $\mathrm{p}-37$

2. Ibid

3. Parasya yatri, $\mathrm{p}-60$ 
4. Ibid, $\mathrm{p}-43$

5. Ibid, p-130

6. Gitanjali poem No.LXVII

7. Diwan of Baba Tahir Uryan Hamadani

8. Gitanjali poem No.LXXXIV

9. Masnavi Manavi book-I, p-I

10. Gitanjali verse No. LIX

مولوى مثنوى، دكتر استعلامى، دفتر پِنجم، ص-133 11

12. Rabindranath Tagore and the growth of monotheist thoughts in India, KarimNajafi Berzger, Especial Tagore's edition of Qand-e- Parsi, p-47

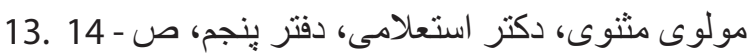

14. Parasya Yatri, p-123

15. Gitanjali verse No. XI

16. Quran, 53/39

17. ITV-

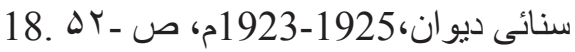

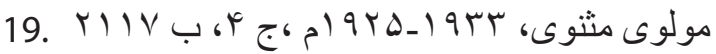

20. FV9 حاج وملا هادى سبزوارى، ديوان،

21. Quran, $50 / 16$

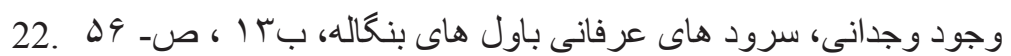

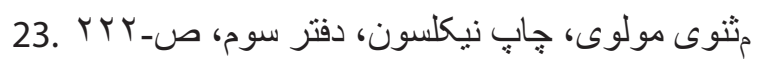

24. Gitanjali verse No. I 
Philosophical Affinity between Tagore and Sufi Poets of Iran

25. Gitanjali. p-LXVII

26. Journey to Persia and Iraq, p 140

\section{REFERENCES:}

Parasya Yatri- by Rabindranath Tagore, Visva-Bharati Publication, 1985

Gitanjali, by Rabindranath Tagore, Rupa \& Co., 2011

Journey to Persia, Rabindranath Tagore, Visva-Bharati Publication, Jan,2003

طوطى هند سوى جمن (مسافر اير ان) از رابندر ا نات تاكور ، ترجمه دكتر نباز احمد خان، انتشار ات وشو ا بار اتى، 2004

قند يارسى، شمارة -49 50 ، يُائيز -زمستان، 1389ه.ش، ويزّه نامه تاكور

$$
\text { مثنوى مولوى جابٍ نيكلسون }
$$

$$
\text { (مثنوى مولوى دكتر استعلامى دفتر ينجم ص133-(عثق جوشد }
$$

حاج ملا هادى سبز وارى، ديو ان، 1372ه.ش، دانشكدة ادبيات و علوم انسانى،

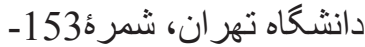
سنائى، ديو ان، 1933-1925م

وجود وجدانى (سرودهاى عرفانى با ولهاى بنگالله) انتشار ات وشو ا بار اتى، 2004

غلام رضا انصاف يور ، روند نهضت هاى ملى و اسلامى در اير ان، سازمان انتشار ات و آموزش انقلاب اسلامى، تهران، 1359 